\title{
ASUPAN GIZI BALITA YANG BERADA DI TEMPAT PENGUNGSIAN KABUPATEN KARANGASEM
}

\author{
Hesteria Friska Armynia Subratha \\ Program Studi Diploma III Kebidanan, STIKES Advaita Medika Tabanan \\ Korespondensi penulis: hesteria.friska@yahoo.com
}

\begin{abstract}
Abstrak
Latar belakang dan tujuan: Pada bayi, balita dan anak, dampak pengungsian yang timbul dalam bidang kesehatan yaitu resiko terjadinya penyakit infeksi, defisit nutrisi, gangguan tumbuh kembang dan gangguan psikososial. Meski jarang terjadi, letusan Gunung Agung termasuk yang terbesar di antara aktivitas vulkanik global dalam 100 tahun terakhir. Lebih dari 1.000 orang meninggal dalam letusan terakhir pada 1963 Gunung Agung adalah satu dari sekian banyak gunung berapi di Indonesia dan wilayah Cincin Api yang mengelilingi Samudera Pasifik dan Samudera Timur India. Penelitian ini bertujuan untuk mengetahui gambaran asupan gizi balita yang berada di tempat pengungsian Kabupaten Karangasem. Metode: Penelitian ini menggunakan metode kualitatif dengan mengunakan studi kasus karena permasalahan gizi balita berbeda. Pada penelitian ini, sumber data yang digunakan antara lain data primer yaitu data yang diperoleh dan dikumpulkan secara langsung dari informan pada satu waktu tertentu. Hasil: Ibu menyusui di tempat pengungsian Kabupaten Karangasem mengalami hambatan dalam pemberian ASI. Makanan yang diberikan pada balita di tempat pengungsian belum dapat memenuhi kebutuhan gizi balita baik dari jumlahnya dan jenis makanannya. Simpulan: Penyediaan makanan direncanakan dengan baik sesuai kebutuhan gizi kelompok umur dan disediakan bilik menyusui serta segera dibangun dapur umum MPASI di posko pengungsian.
\end{abstract}

Kata Kunci: balita, gizi, pengungsian

\section{Pendahuluan}

Lembaga Peserikatan Bangsa-Bangsa (PBB) melaporkan, ada sekitar 6,3 juta anak yang meninggal dunia sebelum berumur 15 tahun, pada 2017. Artinya, ada satu anak yang meninggal setiap lima detik. Hal ini disebabkan tidak adanya air, sanitasi, nutrisi dan layanan kesehatan yang memadai. Sebanyak 5,4 juta anak meninggal pada lima tahun pertama di kehidupannya. Sementara sisanya terjadi pada bayi yang baru lahir (National Geografic Indonesia, 2018). Di Indonesia jumlah kematian balita telah berkurang dari 385.000 jiwa pada tahun 1990 menjadi 152.000 jiwa pada tahun 2012, namun masih terdapat kejadian yaitu lebih dari 400 anak-anak meninggal setiap harinya (Kearnay,2013). SDKI (2012), menunjukan bahwa angka kematian bayi dan balita untuk periode lima tahun sebelum survei masing- masing adalah 32 dan 40 kematian per 1.000 kelahiran hidup.

Dalam lima tahun terakhir, Indonesia dilanda berbagai bencana yang menelan banyak korban jiwa dan harta. Masalah kesehatan utama yang muncul akibat bencana adalah masalah gizi dan penyakit menular. Bencana yang diikuti dengan pengungsian berpotensi menimbulkan masalah kesehatan yang sebenarnya diawali oleh masalah bidang/sektor lain. Bencana gempa bumi, banjir, longsor dan letusan gunung berapi, dalam jangka pendek dapat berdampak pada korban meninggal, korban cedera berat yang memerlukan perawatan intensif, peningkatan risiko penyakit menular, kerusakan fasilitas kesehatan dan sistem penyediaan air. Pada bayi, balita dan anak, dampak pengungsian yang timbul dalam bidang kesehatan yaitu resiko terjadinya penyakit infeksi, defisit 
nutrisi, gangguan tumbuh kembang dan gangguan psikososial (Anonim, 2010). UNICEF (2012), menyatakan bahwa sasaran utama intervensi pada keadaan darurat pasca bencana yaitu balita atau anak di bawah usia lima tahun karena angka kematian balita adalah dua kali lipat dari kelompok usia lainnya.

Hasil penelitian Ana di Posko Pengungsian Mesjid Amal Bhakti Akibat Bencana Erupsi Gunung Sinabung Kabupaten Karo tahun 2015 menyatakan tingkat kecukupan gizi anak balita di setiap minggunya, ada yang tercukupi gizinya dan ada yang tidak tercukupi gizinya. Hasil penelitian menunjukkan bahwa anak balita yang kecukupan energinya Baik dengan kecukupan protein berlebih adalah satu orang (10\%), anak balita yang kecukupan energinya sedang dengan kecukupan protein berlebih adalah lima orang (50\%), anak balita yang kecukupan energinya kurang dengan kecukupan protein berlebih adalah dua orang (20\%), anak balita yang kecukupan energinya Defisit dengan kecukupan protein Berlebih adalah satu orang (10\%), dan anak balita yang kecukupan energinya Kurang dengan kecukupan protein Baik adalah satu orang (10\%). Penelitian yang dilakukan Salmayanti dkk di Kabupaten Aceh Jaya tahun 2016 menyatakan bahwa persediaan makanan yang tidak mencukupi mempengaruhi derajat kesehatan selama berada di pengungsian.

Erupsi Gunung Agung pada tanggal 25 November 2017, membuat warga yang tinggal enam kilometer dari kawah dan sektoral 7.5 kilometer dari kawah harus mengungsi (Saut, 2017). Badan Nasional Penanggulangan Bencana (BNPB) (2017), menyatakan bahwa terdapat 49.485 orang di enam desa yang masuk kawasan rawan bencana Gunung Agung. Rekapitulasi data pengungsi peningkatan aktivitas Gunung Agung pada tanggal 10 Januari 2018, total seluruh pengungsi yaitu 5.272 orang dengan jumlah titik pengungsian yaitu 233 (Dikti, 2018). Kabupaten yang digunakan sebagai tempat pengungsian yaitu Kabupaten Karangasem dengan jumlah lokasi 133, Kabupaten Klungkung dengan jumlah lokasi
38, Kabupaten Buleleng dengan jumlah lokasi delapan, Kabupaten Bangli dengan jumlah dua, lokasi, Kabupaten Gianyar dengan delapan lokasi, Kabupaten Tabanan dengan jumlah 10 lokasi, Kota Denpasar dengan jumlah enam lokasi, Kabupaten Badung dengan jumlah lima lokasi, dan Kabupaten Jembrana dengan jumlah 23 lokasi. Pengungsian di Kabupaten Karangasem berjumlah 1.561 jiwa yang terdiri dari 795 jiwa laki-laki dan 766 jiwa perempuan. Di Kabupaten Karangasem terdapat 122 jiwa balita yang tersebar di 37 titik pengungsian.

Berdasarkan laporan tim kesehatan posko pengungsian, jumlah pengungsi yang berobat ke pos pelayanan kesehatan mencapai 100 orang per hari. Beberapa pengungsi bahkan sampai ada yang harus dirujuk ke rumah sakit daerah. Jenis penyakit yang terbanyak adalah dermatitis, infeksi saluran pernafasan atas (ISPA), diare, dan gangguan pencernaan. Menurut laporan Dinas Kesehatan Provinsi Bali asupan makanan bagi bayi atau balita seperti susu, bubur dan makanan pendamping untuk asupan gizi anak di tempat pengungsian masih sangat minim (Idn Times, 2017). Penelitian tentang gizi balita di tempat pengungsian masih jarang dilakukan di Bali maupun di Indonesia. Penelitian ini dilakukan untuk mengetahui gambaran asupan gizi balita yang berada di tempat pengungsian Kabupaten Karangasem.

\section{Metode Penelitian}

Penelitian ini menggunakan metode kualitatif dengan mengunakan studi kasus karena permasalahan gizi balita berbeda. Pada penelitian ini, sumber data yang digunakan antara lain data primer yaitu data yang diperoleh dan dikumpulkan secara langsung dari informan pada satu waktu tertentu. Partisipan dalam penelitian ini adalah orang tua yang terdiri dari bapak dan ibu. Instrument dalam penelitian ini adalah peneliti sendiri. Pada saat wawancara peneliti menggunakan pedoman wawancara yang dilengkapi dengan catatan lapangan. Alat bantu yang peneliti gunakan adalah $m p 4$ sebagai alat perekam dan alat tulis. Metode 
analisa dalam penelitian ini adalah dengan menggunakan metode Colaizzi. Hal yang paling penting dalam metode ini adalah mengembalikan kembali hasil wawancara yang sudah dibuat verbatim dan digolongkan ke tema-tema kepada partisipan untuk selanjutnya dicek dan apabila ada yang kurang akan dilengkapi oleh partisipan. Etik penelitian dalam penelitian ini dimulai dengan penandatanganan informed consent dimana hal tersebut merupakan bukti bahwa partisipan bersedia terlibat dalam penelitian tersebut.

\section{Hasil dan Pembahasan Karakteristik partisipan}

Partisipan dalam penelitian ini adalah orang tua (bapak dan ibu) yang memiliki anak balita merupakan korban erupsi Gunung Agung dan tinggal di tempat pengungsian Kabupaten Karangasem. Umur partisipan antara 25 tahun sampai dengan 35 tahun. Tingkat pendidikan mulai dari SMP sampai dengan SMA. Jumlah anak bervariasi ada yang mempunyai satu anak, dua anak bahkan ada yang mempuyai tiga orang anak. Keseluruhan partisipan sudah tinggal di tempat pengungsian selama kurang lebih enam bulan.

\section{Pola Pemberian ASI Pada Balita di Tempat Pengungsian}

Ibu menyusui di tempat pengungsian mengalami beberapa hambatan dalam menyusui. Hamabatan yang dirasakan dikarenakan oleh kehilangan kepercayaan diri untuk tetap menyusui dan memberikan ASI untuk bayinya. Bencana alam yang menimpa mereka mengakibatkan ibu dalam kondisi stres penuh tekanan, panik, tidak tenang, takut dan sedih seperti pernyataan sebagai berikut: "air susu saya ga mau keluar mungkin karena kepikiran rumah" (P2). "ASI saya keluarnya sedikit sedikit dan anak saya ga mau disusui" (P4). "Sejak pindah ke sini ASI saya kering" (P5). Kebiasaan anak dalam menyusui mengalami perubahan. Hal tersebut dinyatakan dalam pernyataan sebagai berikut: "Belakangan ini anak tiang ga mau disusui. Sudah tiga hari perilakunya berubah. "Tiang jadi bingung. Mau kasih bubur, saya mau ambil dari mana? Juga sebelumnya tidak pernah diberi bubur, kecuali ASI. Ternyata ASI tiang rasanya tawar, keruh, dan ga kental," (P6).

Ibu-ibu yang mengalami hambatan dalam pemberian ASI mengatakan bahwa mereka tidak bisa menyusui karena mersasa tidak nyaman berdada di tempat pengungsian. Mereka menyatakan malu menyusui di tempat umum sehingga mereka enggan memberikan ASI kepada bayinya. Berikut pernyataannya: "Tiang malu kalau harus nyonyonin di tenda gek. Banyak orang tiang ga nyaman" (P6). "Di sini ga ada tempat tertutup untuk menyusui. Saya malu nyusui kalau banyak ada cowok' (P5).

\section{Pola Pemberian Makanan Pada Balita Di Tempat Pengungsian}

Pada awal tinggal di posko pengungsian para balita mengalami kesulitan makan. Pernyataannya adalah sebagai berikut: "waktu sampai di sini ga mau makan, sampai dipaksa makan tetap ga mau karena ga sesuai seleranya" (P2). "nasi yang sudah dimasukkan dikeluarkan lagi" (P3). Nafsu makan balita di tempat pengungsian di Kabupaten Karangasem mengalami penurunan. Balita yang sebelumnya makan secara teratur sekarang jadi lebih malas untuk makan. "Biasanya putu bangun tidur enam atau setegah tujuh, lalu tiang mandikan dan kasi makan. Sejak pindah ke sini putu jadi malas makan" (P2). "Pas ngungsi ke sini makannya jadi susah, pernah satu hari mogok makan" (P4). "Anak saya sehat, tidak sempat sakit seperti anak lainnya tapi ga mau makan. Di rumah biasanya saya buatkan bubur atau nasi tim ditambah minyak ikan karena di sini tidak ada minyak ikan anak saya ga mau makan" (P5).

Terbatasnya variasi jenis makanan membuat pola konsumsi balita berubah. "Biasanya satu hari makan bisa sampai tiga kali. Waktu pindah ke sini makan cuma 1-2 kali saja" (P2). "Kalau di rumah gampang ngasi makan, kalau di sini ga mau makan karena lauknya dia ga suka" (P4). Balita 
yang sudah bisa makan sendiri jadi malas makan bila tidak disuapi. Pernyataan selangkapnya adalah sebagai berikut: "Sekarang kalau mau makan harus disuapin, kalau ga disuapin dia ga mau makan" (P1). "Saya dan suami gantian nyuapin putu makan, padahal kemarin-kemarin udah bisa makan sendiri" (P2).

\section{Permasalahan Pemberian Makanan Balita di Tempat Pengungsian}

Terdapat permasalahan pengolahan makanan di tempat pengungsian. Permasalahan tersebut antara lain berupa tidak adanya perbedaan makanan balita dengan orang dewasa di tempat pengungsian ini, balita makan seperti yang dimakan oleh orang tuanya. Selama di pengungsian asupan makanan cukup, namun kandungan gizi kurang diperhatikan. Berikut pernyataannya: "anak saya makan sama seperti yang saya makan karena di sini makanannya terbatas" (P1). "makan mie instan, nasi, ikan kering, dan abon tapi di hari kelima di dapur umum sudah masak makanan yang lebih bergizi bagi anak walau hanya satu kali sehari." (P3). Masalah yang juga dikeluhkan para orang tua adalah minimnya ketersediaan makanan balita berupa susu dan bubur. "anak tiang tidak kebagian susu dan bubur jadi saya terpaksa kasi nasi lembek minggu lalu" (P6). "biasanya anak saya makan bubur 3 kali sehari tapi sekarang hanya 1-2 kali saja karena jatahnya terbatas" (P4).

Orang tua balita menyadari sulitnya memenuhi kebutuhan semua balita karena masih kurangnya bantuan logistik dan tenaga pengolah makanan di tempat pengungsian. "Kami menyadari bahwa dapur umum mungkin tidak sempat untuk memasak makanan untuk anak-anak di sini, mereka kurang orang untuk membuat bubur dan sebagainya" (P1). "Kalau masak kan jadi satu. Sayur dan bek kadang banyak bumbu dan pedas, anak-anak tidak bisa makan" (P2). Tinggal di pengungsian menyebabakan orang tua tidak bisa bekerja. Orang tua balita yang sebagian besar merupakan petani dan peternak sudah tidak mempunyai uang lagi sehingga mereka juga tidak bisa membeli makanan tambahan untuk anak mereka. "Kami di sini sudah bisa makan saja syukur" (P2). "saya kan ga kerja, ga punya uang untuk beli kebutuhan anak-anak" (P4). "Kami yang punya balita atau bayi berharap pemerintah bisa sediakan keperluan susu dan makan anak kami" (P5). Kurangnya gizi yang cukup bagi anak di tempat pengungsian menyebabkan balita sering terserang penyakit seperti diare dan ISPA. "Sebelum pindah ke sini anak saya jarang sakit, kalau sekarang sering pilek. Minggu lalu pilek terus sembuh, sekarang lagi pilek ketularan temennya" (P2). "Sering mencret anak tiang gek. Mungkin makanannya ga bersih" (P6).

\section{Pembahasan}

Menurut Peraturan Pemerintah Republik Indonesia Nomor 21 Tahun 2008 Tentang Penyelenggaraan Penanggulangan Bencana pada kondisi kegawatdaruratan bencana dan di tempat pengungsian terdapat beberapa kelompok yang lebih rentan terhadap efek buruk bencana, yaitu anakanak (termasuk bayi dan balita), ibu hamil, ibu menyusui, lansia, penyandang cacat dan orang sakit. Bayi, balita, serta wanita hamil dan menyusui ini menjadi sasaran empuk berbagai jenis penyakit yang saat ini mewabah di kalangan pengungsi. Kekurangan gizi akan memicu turunnya imunitas atau tingkat kekebalan tubuh terhadap penyakit (Widyatun, 2013).

Berdasarkan wawancara mendalam didapatkan hasil bahwa balita di tempat pengungsian Kabupaten Karangasem tidak mendapatkan asupan gizi yang cukup baik berupa ASI, susu ataupun makanan tambahan lainnya. Dalam penelitian ini didapatkan hasil bahwa ibu menyusui mengalami hambatan dalam pemberian ASI. Hambatan tersebut dikarenakan oleh kehilangan kepercayaan diri untuk tetap menyusui dan memberikan ASI untuk bayinya. Hal lain yang menyebabkan ibu tidak dapat menyusui anaknya karena mereka merasa tidak nyaman berdada di tempat pengungsian dan malu menyusui di tempat umum.

Bayi adalah manusia yang berumur di bawah 12 bulan. Seorang bayi seharusnya 
mendapatkan susu dari ibunya sendiri, yaitu ASI. ASI merupakan standar baku emas pemberian makan bayi sehingga ASI merupakan makanan dan minuman yang terbaik bagi bayi. Bayi 0-6 bulan sebaiknya hanya diberikan ASI saja, tanpa tambahan air minum seperti air putih, madu, teh, jus, sirop, dan lain-lain. ASI terjamin keamanan dan ketersediaannya dengan nutrisi terjamin yang bisa memenuhi kebutuhan bayi meskipun ibu di pengungsian hanya makan makanan yang seadanya saja. ASI selalu terjamin bersih dan segar. Selain mengandung semua nutrisi dan cairan yang bayi butuhkan, di dalam ASI juga terdapat antibodi, antiinfeksi, antiradang, antialergi serta zat-zat penguat kekebalan tubuh yang lain sehingga bayi tetap sehat meski kebersihan di tempat pengungsian tidak terjamin (Roesli, 2008). Dengan terus menyusu dan memperoleh ASI maka bayi dan ibu akan lebih sehat. Bayi akan lebih terlindungi dari infeksi saluran pernafasan (seperti batuk pilek) dan pencernaan (seperti diare) yang rentan mewabah di wilayah pengungsian (Putra (2014), Abbas (2018)).

Pada kondisi bencana para ibu merasa khawatir serta kehilangan kepercayaan diri untuk tetap menyusui dan memberikan ASI untuk bayinya. Ibu akan tetap bisa memproduksi ASI yang berkualitas serta mampu memenuhi kebutuhan bayi meskipun ibu dalam kondisi stress penuh tekanan, panik, tidak tenang, takut dan sedih sekalipun. Ibu hanya perlu tetap menyusui bayi. Saat menyusui akan keluar hormon oksitosin dan prolaktin yang akan membuat ibu merasa nyaman, tenang dan bahagia. Sehingga ibu yang menyusui harus tetap didukung untuk menyusui, meskipun tinggal di tenda-tenda darurat pengungsian. Sebaiknya disediakan bilik menyusui supaya ibu bisa lebih merasa aman saat menyusui bayi mereka. Selain ibu ayah juga dapat membantu menenangkan istrinya dan memberikan pijatan lembut di sekitar tulang belakang. Dukungan dan pijatan suami pada ibu menyusui dapat memperlancar produksi ASI (Prijatni, 2017).
Anak yang terserang diare harus tetap disusui supaya terhindar dari komplikasi fatal dari diare juga supaya lebih cepat sembuh. Ibu yang berhenti menyusui mendadak dalam suasana penuh tekanan seperti ini rentan terkena bendungan ASI, mastitis, abses payudara yang justru membuatnya merasa sakit (Khasanah, 2017). Meneruskan menyusui dan memberikan ASI membuat bayi dan ibu tetap sehat.

Bayi yang kehilangan atau terpisah dari ibunya karena ibu sakit atau meninggal bisa dicarikan donor ASI dengan syarat keluarga menyetujui pemberian ASI donor, identitas donor ASI maupun bayi penerima tercatat, ibu susu dinyatakan sehat oleh tenaga kesehatan serta ASI donor tidak diperjual belikan. Pada kondisi kegawatdaruratan bencana alam akan ada banyak bantuan susu formula. Pemberian susu formula tidak tepat dilakukan di wilayah pengungsian yang fasilitasnya serba terbatas dan darurat. Lingkungan pengungsian tidak bersih sehingga air dan peralatan yang digunakan untuk menyediakan susu formula rentan tercemar oleh bakteri serta kotoran lainnya. Lingkungan pengungsian juga tidak terjamin ketersediaan air bersih untuk kegiatan cuci dot dan peralatan bayi. Susu formula tidak mengandung antiinfeksi juga membutuhkan penggunaan dot untuk pemberian kepada bayi. Di lingkungan pengungsian sangat sulit untuk merebus air sehingga tidak terjamin ketersediaan air hangat untuk melarutkan susu formula sewaktu-waktu, juga sulit untuk mensterilkan dot dan peralatan yang digunakan untuk membuat susu formula. Penelitian UNICEF satu bulan setelah gempa di Yogyakarta di tahun 2006 menunjukkan bayi di tempat pengungsian yang diberikan bantuan susu formula akan mengalami diare dua kali lebih sering daripada bayi yang tidak diberi bantuan susu formula (UNICEF, 2009). Oleh sebab itu, sebaiknya para ibu menyusui tetap meneruskan pemberian ASI bagi bayi dalam situasi gawat darurat bencana.

Dalam penelitian ini didapatkan hasil bahwa balita yang berada di tempat pengungsian Kabupaten Karangasem 
mengalami kesulitan makan. Kurangnya variasi dalam pemberian makanan menyebabkan nafsu makan balita menurun sehingga mereka harus disuapi supaya mau makan. Tinggal di pengungsian, membuat balita kekurangan gizi karena faktor ketersedian makanan gizi tambahan tidak ada. Penelitian yang dilakukan oleh Siagian (2014) tentang penanganan gizi untuk balita dipengungsian menyatakan bahwa penyajian menu makanan untuk anak balita bisa dikatakan minim, karena dapur umum tidak menyiapkan menu khusus untuk anak balita sehingga anak balita hanya mengkonsumsi makanan yang juga dikonsumsi orang dewasa.

Penyelenggaraan makanan darurat dipersiapkan oleh petugas pada waktu terjadi keadaan darurat yang ditetapkan oleh penanggungjawab posko setempat sesuai dengan ketentuan yang telah ditetapkan. Keterbatasan ini menyebabkan petugas posko tidak bisa mengusahakan dan membuat makanannya sendiri. Pemberian pelayanan dan penanganan gizi yang tidak memenuhi kebutuhan gizi balita dapat menimbulkan dampak yang buruk terhadap status gizi balita. Hal tersebut menyebabkan balita sering diserangan penyakit selama di pengungsian seperti diare dan ISPA. Menu untuk orang dewasa didasari oleh ketersediaan bantuan yang diperoleh dari posko yang menyebabkan konsumsi makanan yang tidak beragam dan terbatas seperti kurangnya konsumsi ikan segar, buah, daging dan sebagainya yang merupakan sumber zat gizi guna pertumbuhan dan perkembangan balita.

Orang tua di tempat pengungsian tidak mampu memberikan gizi yang baik bagi anak mereka. Penyebab ketidakmampuan orang tua menyediakan asupan gizi tambahan dikarenakan orang tua tidak memiliki biaya untuk membeli makanan tambahan dan susu. Selama tinggal di pengungsian mereka tidak bisa bekerja sehingga tidak memiliki sumber penghasilan. Selama di pengungsian asupan makanan cukup, namun kandungan gizi kurang diperhatikan, pola asuh orangtua kurang baik, disebabkan stres karena terlalu lama tinggal di pengungsian.

Berdasarkan faktor-faktor tersebut, penelitian ini merekomendasikan agar penyediaan makanan di tempat pengungsian direncanakan dengan baik sesuai kebutuhan gizi kelompok umur. Penelitian ini juga merekomendasikan agar disediakan bilik menyusui dan segera dibangun dapur umum MPASI di posko pengungsian. Hal tersebut disebabkan karena ibu-ibu menyusui merasa malu menyusui di tempat umum. Di posko pengungsian masih banyak petugas yang masih memberikan makanan orang dewasa kepada balita. Selain itu dengan dibangunnya dapur umum MPASI para ibu balita dapat melihat dan turut andil dalam pembuatan makanan anaknya.

\section{Simpulan}

Terdapat beberapa masalah pemenuhan asupan gizi pada balita di tempat pengungsian. Masalah tersebut berupa terhambatnya pemberian ASI dan tidak ada perbedaan jenis makanan pada balita dengan orang dewasa.

\section{Referensi}

Abbas, P., 2018. Hubungan Pemberian Asi Eksklusif Dengan Kejadian Infeksi Saluran Pernapasan Akut (ISPA) Pada Bayi. Jurnal Unnisula.

BNPB, 2018. Rekapitulasi Data Pengungsi Peningkatan Aktivitas Gunung Agung

Idn Times, 2017. Balita di Pengungsian Gunung Agung Butuh Asupan Gizi. Avaible at: https://www.idntimes.com/news/in donesia/yogie/balita-dipengungsian-gunung-agung-butuhasupan-gizi/full.

Khasanah, N.A., Sulistyawati, W., 2017. Asuhan Nifas dan Menyusui. Surakarta: Bebuku Publisher

Kompas, 2017 "Menkes: Anak-anak Pengungsi Gunung Agung Mulai Mengalami ISPA". Avaible at: https://nasional.kompas.com/read/2 017/09/28/20305221/menkes-anak- 
anak-pengungsi-gunung-agungmulai-mengalami-ispa.

National Geografhic Indonesia, 2018. Laporan PBB satu anak di dunia meninggal setiap lima detik. Avaible at: http://nationalgeographic.grid.id/rea d/13940425/laporan-pbb-satu-anakdi-dunia-meninggal-setiap-limadetik?page $=$ all.

Pars Today, 2017. Berbagai Masalah Mulai Dihadapi Pengungsi Gunung Agung. Avaible at:

http://parstoday.com/id/news/indonesiai45033 berbagai_masalah_mulai_dihadapi_ pengungsi_gunung_agung.

Peraturan Pemerintah Republik Indonesia Nomor 21 Tahun 2008 Tentang Penyelenggaraan Penanggulangan Bencana

Prijatni, I., 2017. Peran Suami Dalam Mendukung Kelancaran Pengeluaran Asi Dengan Pijat Oxytocin. Jurnal Idaman, Volume 1, No. 1, Desember 2017: 10-13

Putra, I.A., 2014. Hubungan Pemberian Susu Formula Dengan Kejadiaan Diare Pada Bayi Usia 0-6 Bulan. Jambi Medical Journal" Jurnal Kedokteran.

Roesli, U., 2008 . Mengenal ASI Ekslusif. Jakarta: PT Pustaka Pembangunan Swadaya Nusantara

Sahut, P.D., 2017. Gunung Agung Meletus, Asap Hitam Membumbung Tinggi. Available

https://news.detik.com/berita/37429 65/gunung-agung-meletus-asaphitam-membubung-tinggi

Salmayanti, 2016. Kajian Penanganan Gizi Balita Pada Kondisi Kedaruratan Bencana Banjir Di Kecamatan Sampoiniet Kabupaten Aceh Jaya. Avaible at: http://www.jurnal.unsyiah.ac.id/JK S/article/view/6483/5318. Diakses pada tanggal 4 September 2018.

Siagian, 2014. Gambaran status gizi dan penyakit infeksi pada anak balita
(12-59 bulan) di posko pengungsian erupsi gunung Sinabung Kabupaten Karo tahun 2014. Universitas Sumatra Utara 